\title{
Epigenetic Modifications in Essential Hypertension
}

\author{
Ingrid A. Wise and Fadi J. Charchar * \\ Faculty of Science \& Technology, Federation University Australia, University Drive, Mount Helen, VIC 3350, \\ Australia; i.wise@federation.edu.au \\ * Correspondence: f.charchar@federation.edu.au; Tel.: +61-353-276-098
}

Academic Editor: Anastasia Susie Mihailidou

Received: 16 February 2016; Accepted: 21 March 2016; Published: 25 March 2016

\begin{abstract}
Essential hypertension (EH) is a complex, polygenic condition with no single causative agent. Despite advances in our understanding of the pathophysiology of $\mathrm{EH}$, hypertension remains one of the world's leading public health problems. Furthermore, there is increasing evidence that epigenetic modifications are as important as genetic predisposition in the development of $\mathrm{EH}$. Indeed, a complex and interactive genetic and environmental system exists to determine an individual's risk of EH. Epigenetics refers to all heritable changes to the regulation of gene expression as well as chromatin remodelling, without involvement of nucleotide sequence changes. Epigenetic modification is recognized as an essential process in biology, but is now being investigated for its role in the development of specific pathologic conditions, including EH. Epigenetic research will provide insights into the pathogenesis of blood pressure regulation that cannot be explained by classic Mendelian inheritance. This review concentrates on epigenetic modifications to DNA structure, including the influence of non-coding RNAs on hypertension development.
\end{abstract}

Keywords: essential hypertension; epigenetics; DNA methylation; histone modifications; non-coding RNA; microRNAs

\section{Introduction}

Hypertension (HT) affects more than 1 billion people globally and is a major risk factor for stroke, chronic kidney disease, and myocardial infarction [1]. Despite advances in our understanding of the pathophysiology of HT and the implementation of more effective treatment and prevention strategies, HT remains one of the world's great public health problems [2]. The public health impact created by HT is due to its contribution to cardiovascular disease (CVD) events, such as heart attack, congestive heart failure, peripheral vascular disease, and stroke [3]. Essential hypertension (EH) is a complex, polygenic condition with no single causative agent. Furthermore, there is increasing evidence that epigenetic modifications are as important as genetic predisposition in the development of EH. Indeed, a complex and interactive genetic and environmental system exists to determine an individual's risk of EH (Figure 1).

Epigenetic modification is recognised as essential in biological processes and in recent years there has been studies investigating its role in the development of specific pathologic conditions. Research into epigenetic mechanisms will provide insights into the pathogenesis of blood pressure regulation that cannot be explained by classic Mendelian inheritance. Previous reviews in this field report on the various epigenetic mechanisms impacting CVD [4-6] or they discuss a selection of epigenetic modifications in the context of HT but exclude some recent, important findings, such as the influence of long non-coding RNAs on HT [7-10]. This review concentrates on epigenetic modifications to DNA structure, including the influence of non-coding RNAs on EH development. 


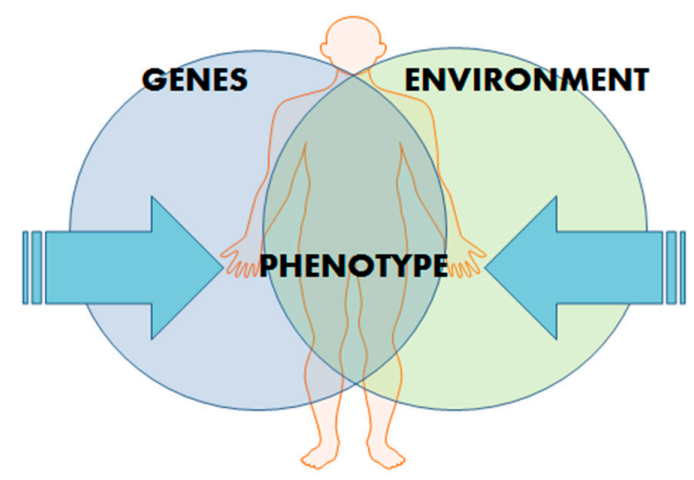

Figure 1. Influences on phenotype manifestation. Development of polygenic conditions, such as essential hypertension (EH), depend on a complex but interactive genetic and environmental system.

\section{Epigenetics}

Epigenetics refers to all heritable changes to the regulation of gene activity, without changes to the DNA sequence itself [11]. In other words, "epigenetics" refers to analysis of the human genome from the perspective of chromatin and chromosomes, as well as to the quintessential issue of the DNA sequence. Epigenetic modifications can be provoked by a variety of factors, including environmental influences during foetal and childhood development, chemical exposure, aging, dietary habits, and the use of recreational drugs and some prescription medications [10].

The launch of international initiatives, the Human Epigenome Project [12], which first released data in 2003, and the International Human Epigenome Consortium [13] formed in 2010, attest to the rapid expansion of interest in epigenetics. Epigenetic inheritance is an essential mechanism that enables the stable propagation of gene activity states from one generation of cells to the next [14]; it is helping to resolve puzzling aspects of heredity, while explaining how the same genome can give rise to apparently contrasting phenotypic traits [15]. Chromatin consists of nucleosomes: DNA strands wrapped around histones. Several distinct biochemical processes can epigenetically modify both DNA and histones [10]. These include DNA methylation (Figure 2), post-translational histone modifications (Figure 3), and RNA-based mechanisms mediated by small non-coding microRNAs [16] (Figure 4).

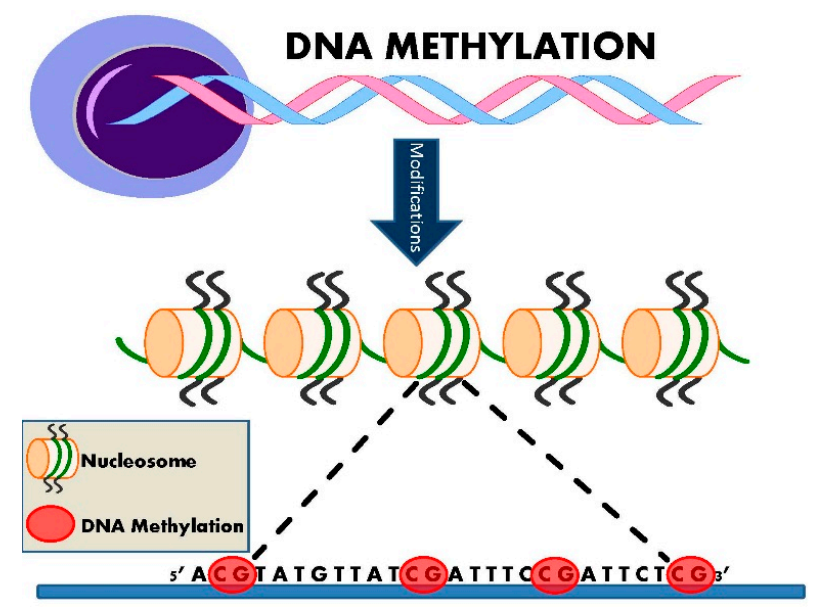

Figure 2. Epigenetic DNA methylation. DNA methylation involves the binding of a methyl group to the 5' carbon of cytosine ring. This primarily occurs at $\mathrm{CpG}$ islands and results in inhibition of gene transcription, particularly if it occurs in the gene promoter region. It may also promote transcription if it is located at gene exons sites. DNA methylation is an essential biological process which is linked with several epigenetic phenomena including $\mathrm{X}$-chromosome inactivation, genomic imprinting and repetitive element repression. 


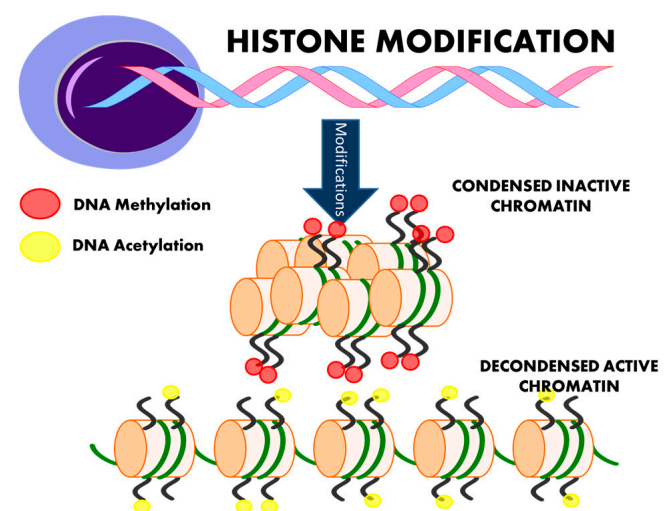

Figure 3. Histone modification. Post-translational changes in the form of histone modifications influence gene expression by controlling chromatin dynamics. Methylation is commonly associated with gene silencing and can directly interfere with the binding of transcription factors. Histone tail acetylation can increase the access of transcription factors to DNA by transforming condensed chromatin into a more relaxed structure.

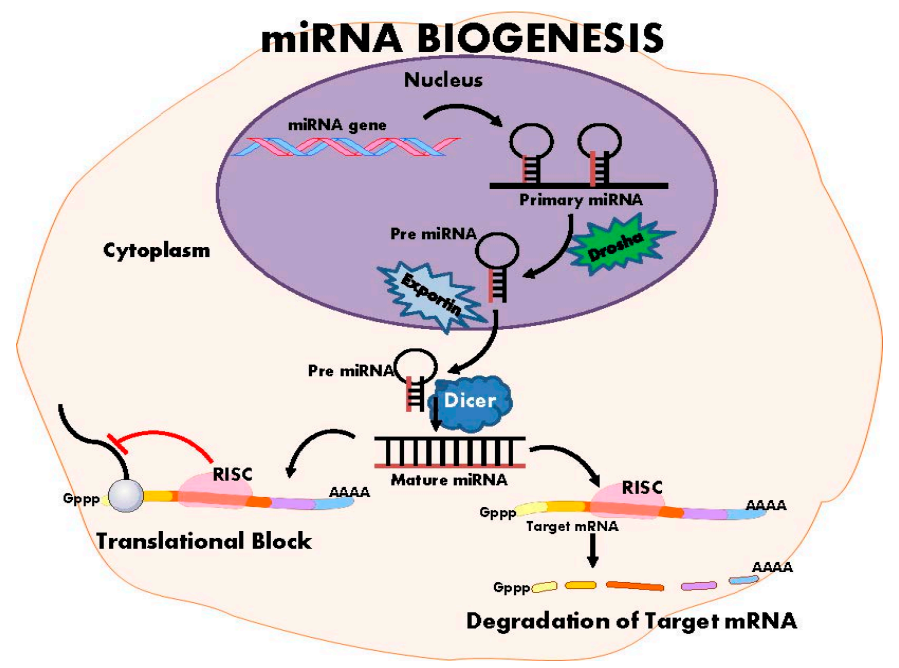

Figure 4. MicroRNA biogenesis. MiRNA biogenesis involves down-regulation of gene transcription via target mRNA degradation or by mRNA translation blockage. RISC: RNA-induced silencing complex.

\section{DNA Methylation}

Epigenetic DNA modification (methylation) occurs when a methyl group derived from $S$-adenosyl-L-methionine is bound to position 5 of the cytosine ring, forming 5-methyl-cytosine (5mC) [17] (Figure 2). This happens at specific dinucleotide sites called CpGs, as these are prone to such modifications [10]. CpG islands are short sequences of DNA with a high linear frequency of 5'-CpG-3" sequences. The " $\mathrm{P}$ " denotes the phosphoesteric bond linking the cytosine and the guanine nucleotides [9]. CpG islands are often located in the promoter regions and approximately $40 \%$ of genes contain CpG islands in the end 5' region (promoter, untranslated region, and exon1). The rest of the genome (intergenic and intronic regions) is considered $\mathrm{CpG}$ poor [17]. In healthy somatic cells, up to 90\% of CpG dinucleotide sites are methylated, except for those located in the promoter region, which appear to be somewhat protected from such modification [17]. Non-CpG island DNA methylation has also been reported to influence protein-DNA interactions, gene expression and chromatin structure, and stability [18] (Table 1). Functionally, DNA methylation suppresses gene transcription, so DNA hypermethylation results in gene silencing [10]. 
Different degrees of DNA methylation have been correlated with variable onset, timing, and severity of EH (Table 1) [10,19]. Global genomic DNA methylation can be quantified by measuring the amount of 5-methyl cytosine present in a DNA sample. Smolarek et al. [19] found a correlation between decreased levels of $5 \mathrm{mC}$ in peripheral blood with an increase in $\mathrm{EH}$ grade severity. The concentration of $5 \mathrm{mC}$ was calculated as a ratio of spot intensities and a significant deficit in $5 \mathrm{mC}$ was observed in healthy controls, relative to levels found in the two severity grades of $\mathrm{EH}$. The mean level of $5 \mathrm{mC}$ was $1.80 \pm 0.69$ in healthy controls and $1.14 \pm 0.48$ in all hypertensive subjects (specifically, $1.29 \pm 0.50$ grade 1, $0.99 \pm 0.42$ grade 2), indicating that global DNA methylation levels decrease as the severity of $\mathrm{EH}$ increases. However in this study, the percentage of $5 \mathrm{mC}$ was expressed as a coefficient " $R$ " value, and the method for calculating " $R$ " was not disclosed.

Table 1. Summary of methylation findings in relation to hypertension.

\begin{tabular}{|c|c|c|}
\hline Reference & Tissue Type/Sample Size & Findings \\
\hline Smolarek, et al. [19] & $\begin{array}{l}\text { Human: Peripheral blood; } 60 \text { with EH; } \\
30 \text { controls }\end{array}$ & $\begin{array}{l}\text { Mean } 5 \mathrm{mC} \text { amount in DNA significantly } \\
\text { decreased as HT severity increased. }\end{array}$ \\
\hline Kato, et al. [20] & $\begin{array}{l}\text { Human: Peripheral blood, cord blood, } \\
\text { muscle, liver, fat; } 320,251 \text { individuals } \\
\text { of East Asian, European and South } \\
\text { Asian ancestry }\end{array}$ & $\begin{array}{l}\text { Multiple genetic variants involved with } \\
\text { vascular smooth muscle (IGFBP3, KCNK3, } \\
P D E 3 A, P R D M 6) \text { and renal function } \\
\text { (ARHGAP24, OSR1, SLC } 22 A 7, T B X 2) \\
\text { discovered to be correlated with BP } \\
\text { modulation. Two-fold enrichment } \\
\text { discovered between DNA methylation } \\
\text { and sentinel blood pressure SNPs, } \\
\text { providing evidence for DNA methylation } \\
\text { role in blood pressure regulation. }\end{array}$ \\
\hline Friso, et al. [21] & $\begin{array}{l}\text { Human: Peripheral blood; } 25 \text { with EH; } \\
32 \text { with prednisone therapy }\end{array}$ & $\begin{array}{l}\text { HSD11B2 gene promoter methylation } \\
\text { associated with EH onset via disruption } \\
\text { to THF/The ratio. }\end{array}$ \\
\hline Goyal, et al. [22] & $\begin{array}{l}\text { Rat: Tissues: brain; } 20 \text { MLP pups, } 17 \\
\text { control pups }\end{array}$ & $\begin{array}{l}\text { Hypomethylation of RAAS system genes } \\
\text { such as ACE resulting in HT in offspring. }\end{array}$ \\
\hline Wang, et al. [23] & $\begin{array}{l}\text { Human: Peripheral blood; } 8 \mathrm{EH} \text {; } \\
8 \text { control }\end{array}$ & $\begin{array}{l}P R C P \text { gene hypomethylated in } \mathrm{EH} \text {, linked } \\
\text { to disruption in cleavage of angiotensin II } \\
\text { and III. }\end{array}$ \\
\hline Pei, et al. [24] & $\begin{array}{l}\text { Rat: Tissue: aorta; } 6 \text { Spontaneously } \\
\text { HT; } 6 \text { WKY control }\end{array}$ & $\begin{array}{l}\text { Atgr1a gene progressively } \\
\text { hypomethylated as SHR age progressed. } \\
\text { Indicating increased expression of Atgr1a } \\
\text { in aging SHR. }\end{array}$ \\
\hline Riviere, et al. [25] & $\begin{array}{l}\text { Rat: Cultured endothelial cells } \\
\text { from WKY }\end{array}$ & $\begin{array}{l}\text { Hypermethylation associated with } \\
\text { trasciptional repression of sACE, } \\
\text { indicating a role for epigenetics in } \mathrm{SACE} \\
\text { modulation during HT. }\end{array}$ \\
\hline Lee, et al. [26] & $\begin{array}{l}\text { Rat: Tissues: aorta, heart; SHR } \\
\text { and WKY }\end{array}$ & $\begin{array}{l}\text { Hypomethylation of } \operatorname{Sic} 2 a 2 \text { gene lead to } \\
\text { increased expression of NKCC } 1 \text { which } \\
\text { was positively correlated with HT. }\end{array}$ \\
\hline
\end{tabular}

EH: essential hypertension; MLP: maternal low protein; HT: Hypertension; SHR: spontaneously hypertensive rat, WKY: Wistar Kyoto rat; 5mC: 5-methyl-cytosine; ACE: angiotensin converting enzyme; RAAS: renin-angiotensin-aldosterone system; sACE: somatic ACE; SNPs: single nucleotide polymorphisms; NKCC1: $\mathrm{Na}^{+}-\mathrm{K}^{+}-2 \mathrm{Cl}^{-}$cotransporter 1; BP: blood pressure.

The most robust data on the involvement of methylation in blood pressure regulation comes from the study by Kato et al. [20]. Kato and colleagues performed a genome-wide association and replication study and identified genetic variants at 12 new loci that correlated with blood pressure modulation in 320,251 individuals of East Asian, European, and South Asian ancestry [20]. An investigation of the relationship between the sentinel blood pressure single nucleotide polymorphisms (SNPs) with local DNA methylation in 1904 South Asians (peripheral blood; Illumina Human Methylation 450 Bead Chip array (Erasmus Medical Centre, Rotterdam, The Netherlands)) revealed a two-fold enrichment between 
sequence variation and DNA methylation. Twenty-eight of the 35 sentinel SNPs were associated with one or more methylation markers [20], suggesting that DNA methylation may lie on the regulatory pathway linking sequence variation and blood pressure. Genes associated with the 12 newly identified SNP loci include those involved with vascular smooth muscle (IGFBP3, KCNK3, PDE3A, PRDM6) and renal function (ARHGAP24, OSR1, SLC22A7, TBX2) [20]. Investigation of cross-tissue patterns of DNA methylation at the leading $26 \mathrm{CpG}$ sites associated with the sentinel SNPs showed that DNA methylation in the blood was closely correlated with methylation patterns of various tissues (liver, muscle, subcutaneous and visceral fat). While these potentially ground-breaking results indicate that methylation levels in blood may provide a proxy for methylation patterns in other tissues, further research is needed to investigate this correlation with a hypertensive affector organ, such as the kidney.

Initial DNA methylation research centred on correlating EH with the global level of 5mC [19], but more recent studies have focused on the methylation of specific DNA sequences. The hydroxysteroid dehydrogenase-11ß2 enzyme (HSD11B2) converts cortisol to cortisone, which is found in circulatory concentrations up to 1000 times higher than aldosterone (the primary mineralocorticoid hormone and sodium $(\mathrm{Na})$ transport modulator of the renin-angiotensin-aldosterone system (RAAS)) [10]. Cortisol and aldosterone bind mineralocorticoid receptors with equal affinity, but due to the difference in concentration of the hormones, cortisol has a larger role in sodium reabsorption by the kidneys and, in consequence, plays a larger role in fluid-related arterial pressure [10]. HSD11B2-mediated degradation of cortisol to cortisone is disrupted when the promoter region of the HSD11B2 gene is hypermethylated $[27,28]$. The resulting imbalance in the active metabolites of cortisol and cortisone, tetrahydrocortisol (THF), and tetrahydocortisone (THE), respectively, promotes the onset of HT [27,28], in accord with the findings by Friso et al. [21]. Friso et al. [21] also found that HSD11B2 promoter methylation was associated with $\mathrm{EH}$, with parallel disruptions to the THF/THE ratio.

Due to the well-known involvement of the RAAS system on arterial pressure regulation, any changes in the activation status of RAAS-regulated genes have a pronounced effect on an individual's potential to develop HT. This effect has been extensively tested in animal models of HT [29]. Hypomethylation of the promoter regions of the angiotensin II type $1 \mathrm{~b}$ receptor gene in the adrenal glands of the maternal low protein (MLP) rat promoted HT through an exaggerated response to salt [29]. The same effect was seen in a second study, where maternal protein deficiency during pregnancy induced hypomethylation of the promoter regions of RAAS-responsive genes, such as angiotensin converting enzyme (ACE), causing predisposition to HT in offspring as well as cognitive deficits [22]. The human PRCP gene encodes a lysosomal prolylcarbopeptidase protein, which is implicated in cleavage of c-terminal amino acids linked to proline in peptides such as angiotensin II and III [30]. Methylation profiling conducted on young African males revealed that the PRCP gene was hypomethylated in EH subjects [23]. Similarly, when expression patterns of the angiotensin 1a receptor (Atgr1a) were analysed in both spontaneously hypertensive rat (SHR) and its normotensive control, the Wistar Kyoto rat (WKY), expression of Atgr1a was significantly increased by week 20 in the SHR. Bisulfite sequencing revealed that the Atgr1a promoter from endothelial cells in the aorta and mesenteric arteries of the SHR rats became progressively hypomethylated with age compared to their WKY counterparts [24], suggesting heightened Atgr1a expression in the SHR was related to the hypomethylation of the Atgr1a promoter and may have a role in the maintenance of high blood pressure. Somatic ACE (sACE) converts angiotensin I to the active form, angiotensin II and is, therefore, a key regulator of blood pressure [25]. Bisulfite sequencing conducted on cultured endothelial cells and Wistar Kyoto rats revealed that hypermethylation was associated with transcriptional repression of sACE, indicating possible epigenetic involvement of sACE modulation in HT [25].

Membrane transporters such as $\mathrm{Na}^{+}-\mathrm{K}^{+}-2 \mathrm{Cl}^{-}$cotransporter 1 (NKCC1), participate directly with fluid and electrolyte loss and therefore arterial pressure regulation [26]. NKCC1, expressed by the Sic2a2 gene, mediates the transport of sodium, potassium and chloride into and out of the cells [10]. Changes in ion fluxes have been implicated in $\mathrm{EH}$, particularly an augmented, passive influx $\mathrm{Na}^{+}$, $\mathrm{K}^{+}, \mathrm{Rb}^{+}$, and $\mathrm{Cl}^{-}$in hypertensive vascular smooth muscle cells [26]. Hypomethylation of the Sic $2 a 2$ 
gene promoter in the SHR aorta and heart, result in increased expression of $\mathrm{NKCC1}$ and is positively correlated with HT [26].

Methyl CpG binding protein 2 methylates the norepinephrine transporter gene, silencing its expression [10]. Hypermethylation of the norepinephrine transporter gene, which transports norepinephrine and dopamine from the synaptic gap back to the pre-synaptic neuron, has been shown to lead to increased transport responsiveness, resulting in EH [31]. Furthermore, phenyl-ethanolamine $N$-methyltransferase (PNMT), which can act similarly to methyl CpG binding protein 2, has been shown to exacerbate the decrease in norepinephrine uptake, thereby enhancing the local and systemic catecholaminergic effect [31].

\section{Histone Modification and Hypertension}

DNA is packaged into the dynamic protein structure of chromatin, whose basic unit is the nucleosome. A nucleosome comprises of two copies each of the histone proteins H2A, H2B, H3, and $\mathrm{H} 4$ [32]. Post-translational modifications regulate gene expression by controlling the dynamics of chromatin. Modifications occurring at residues in histone tails include acetylation and methylation (Figure 3) as well as phosphorylation, sumoylation, and biotinylation [32].

Epigenetic histone modification occurs when the N-terminal tail is subjected to a variety of post-translational modifications [10]. Up to 60 possible modifications can occur. Specifically, the nucleotide lysine can be modified by methylation, acetylation, ubiquitylation, or sumoylation, whereas arginine can only be modified by methylation, and serine and threonine are modified only by phosphorylation [10]. While each histone modification pattern has a unique impact on the corresponding nucleosome, generally, the outcomes are similar: histone acetylation promotes gene transcription while deacetylation represses transcription; histone lysine methylation in position 79 inhibits while histone arginine methylation activates gene transcription; histone lysine hypermethylation or mono-methylation at position 9 can have opposing effects-respectively silencing or activating the target gene [9] (Table 2).

Table 2. Summary of histone modification findings in relation to hypertension.

\begin{tabular}{|c|c|c|}
\hline Reference & Tissue Type/Sample Size & Findings \\
\hline Han, et al. [33] & $\begin{array}{l}\text { Rat: Tissue: Aorta, renal artery; } \\
\text { SHR and WKY }\end{array}$ & $\begin{array}{l}\text { Up-regulated histone modifier H3K27me3 } \\
\text { in renal artery of SHR correlated with HT } \\
\text { improvement after resveratrol intake. }\end{array}$ \\
\hline Fish, et al. [34] & $\begin{array}{l}\text { Human: Umbilical vein } \\
\text { endothelial cells }\end{array}$ & $\begin{array}{l}\text { Endothelial cell nucleosomes } \\
\text { corresponding to eNOS enriched in } \\
\text { various histones relevant to eNOS } \\
\text { expression. }\end{array}$ \\
\hline Lee, et al. [35] & $\begin{array}{l}\text { Rat: Tissue: adrenal gland, aorta, } \\
\text { heart, kidney, liver, and lung. SHR } \\
\text { and WKY }\end{array}$ & $\begin{array}{l}\text { Higher expression of Ace } 1 \text { mRNA \& } \\
\text { protein in SHR. Ace1 promoter enriched } \\
\text { with H3Ac and H3K } 4 \text { me3 in SHR. }\end{array}$ \\
\hline Cho, et al. [36] & $\begin{array}{l}\text { Rat: Tissue: Mesenteric artery, } \\
\text { aorta; SD and Sham rat. }\end{array}$ & $\begin{array}{l}\text { Nkcc1 up-regulated in SD rat. Acetylated } \\
\text { histone } \mathrm{H} 3 \text { up-regulated, trimethylated } \\
\text { histone } \mathrm{H} 3 \text { down-regulated. }\end{array}$ \\
\hline Duarte, et al. [37] & $\begin{array}{l}\text { Human: Peripheral blood; First } \\
\text { sample: } 206 \text { mixed sex, } \\
\text { normotensive; Second sample: } 730 \\
\text { mixed sex, HT and normotensive. }\end{array}$ & $\begin{array}{l}\text { DOT1L strongly associated with increased } \\
\text { BP in Caucasians. Possibly via mediation } \\
\text { of hypermethylation of } \mathrm{H} 3 \text {. }\end{array}$ \\
\hline $\mathrm{Mu}$, et al. [38] & $\begin{array}{l}\text { Mouse: Tissue: Kidney; } \\
\text { norepinephrine infused-C57 BL/6j, } \\
\text { Adrb1 knockout and Adrb2 } \\
\text { knockout mice. }\end{array}$ & $\begin{array}{l}\text { WNK4 down-regulation caused increased } \\
\text { H3 \& H4 acetylation, leading to } \\
\text { overexpression of NCC and therefore } \\
\text { promoting HT onset. }\end{array}$ \\
\hline
\end{tabular}

eNOS: endothelial nitric oxide synthase; SD: Sprague-Dawley rat; DOT1L: DOT1-like histone H3K79 methyltransferase; NCC: sodium chloride co-transporter; WNK4: with-no-lysine kinase 4. 
Histone modification affecting arterial pressure levels has been documented in a variety of human and animal tissues, including vascular smooth muscle. Vascular oxidative stress can contribute to endothelial dysfunction - a hallmark of HT—and the development of HT. A study by Bhatt et al. [39] documented the beneficial effects of resveratrol on endothelial function in the SHR. A later study of the mechanisms behind this effect was conducted by Han et al. [33]. Epigenetic modifications, in the form of up-regulated H3K27me3 expression was observed in the renal artery of a salt-sensitive hypertension model of the Wistar rat [33], possibly correlating with the improvement observed in HT status but this was not clear. Endothelial nitric oxide synthase (eNOS) is primarily responsible for the production of nitric oxide in the vascular endothelium, and plays a key role in the regulation of vascular tone [33]. eNOS activity is thought to be down-regulated in CVD. Fish et al. [34] found that eNOS expression appears to be controlled by cell-specific histone modifications. They also demonstrated that the nucleosomes of endothelial cells corresponding to the eNOS core promoter were enriched in lysine 9 of histone $\mathrm{H} 3$ and lysine 12 acetylation of histone $\mathrm{H} 4$, and of di- and tri-methylation of lysine 4 of histone H3. Fish et al. [34] observed that all of these epigenetic histone modifications were significantly important for the expression of eNOS [34].

The study by Riviere et al. [25] noting the modulation of sACE by CpG methylation also documented the involvement of histone deacetylases in the same process. Later findings of Lee et al. [35] further validated these observations. Riviere et al. [25] also found that tissues from SHRs exhibit higher expression levels of Ace1 mRNA and protein than those of WKY controls. They found the Ace1 promoter regions of the SHR tissues were more enriched with H3Ac and H3K4me3, and concluded that Ace1 is locally up-regulated in SHR tissues via histone code modifications [35].

In line with observations by Lee et al. [26], Cho et al. [36] found that levels of the membrane transporter Nkcc1 mRNA and protein in the aortas of Sprague-Dawley (SD) rats were significantly increased after administration of an angiotensin II infusion. Cho et al. [36] found that acetylated histone H3 (an activating histone), was significantly increased together with greatly decreased trimethylated histone $\mathrm{H3}$ (a deactivating histone) [36], suggesting that both histone modification and/or DNA demethylation have a role in the epigenetic up-regulation of $N k c c 1$ during HT development.

Disruptor of telomeric silencing-1 (DOT 1), a methyl-transferase, enhances methylation of lysine 79 residue of histone H3 (H3K79) [10]. DOT1-mediated hypermethylation of H3 disrupts silencing of genes associated with maintaining telomere length during DNA repair, located in the telomeric regions of chromosomes [40]. This disruption correlates with a decrease in connective tissue growth factor transcription, increased intracellular cAMP and alterations in the adaption of blood vessels to stressors-associated with HT [40]. In Caucasians, DOT1-like histone H3K79 methyltransferase (DOT1L) is strongly associated with increased blood pressure in response to hydrochlorothiazide [37].

Activation of the renal sympathetic nervous system has long been thought to play a crucial role in the development of salt-reactive HT [41]. Overactivity of renal sympathetic pathways can promote the activation of several mechanisms which lead to increased sodium retention, including stimulation of renin release, reduced renal blood flow, and increased sodium reabsorption in the loop of Henle [42,43]. Serine-threonine kinases have a key role in renal tubular sodium reabsorption; specifically, the with-no-lysine (WNK) family of serine-threonine kinases [44]. In normotensive mice, a low-sodium diet decreases expression of renal WNK4, whereas a high sodium diet increases its expression $[45,46]$. Renal sympathetic activity can also promote sodium reabsorption via activation of the $\beta-2$ adrenergic receptor $\left(\beta_{2}\right.$ AR) leading to cyclic AMP (cAMP) production, and increased activity of renal epithelium sodium channels $(\mathrm{ENaC})$ [30]. WNK4 signalling targets $\mathrm{ENaC}$, and may also mediate the prohypertensive effects of renal sympathetic overactivity. In addition to the classical cAMP pathway, cAMP modulates gene transcription via inhibition histone deacetylase- 8 activity leading to increased histone acetylation $[47,48]$. Mu et al. [38] found that salt loading triggers $\beta$-adrenergic-mediated down-regulation of renal WNK4, increases salt retention, and consequently leads to the development of salt sensitive HT. WNK4 was recently found to be negatively regulated by the glucocorticoid receptor [49]. Mu et al. [38] also noted that the underlying mechanism down-regulating renal WNK4 is 
cAMP dependent modulation of histone acetylation, which consequently increased histone $\mathrm{H} 3$ and $\mathrm{H} 4$ acetylation. Acetylation of $\mathrm{H} 3$ and $\mathrm{H} 4$ seems to favour binding of the glucocorticoid receptor to a WNK4 promoter region that contains a negative glucocorticoid-responsive element [38]. Mu et al. found WNK4 expression was inhibited via these pathways leading to overexpression of the sodium chloride co-transporter (NCC) and the onset of HT [38].

\section{Non-Coding RNAs and Hypertension}

Non-coding RNAs (ncRNA) are implicated in several epigenetic processes, notably small RNAs that can influence histone modifications and cytosine methylation which are connected with gene expression regulation [50]. NcRNA modification can produce effects analogous to classical DNA or histone epigenetic mechanisms described earlier, or can induce HT via separate, distinct processes. Essentially, epigenetics allow the same genome to show alternative phenotypes based on different epigenetic influences. Some of the most complicated and researched epigenetic phenomena including X-chromosome inactivation, parental imprinting and paramutation have an RNA contribution, either directly or indirectly [50]. While most ncRNAs have no identified function yet, it is conceivable that all are participants in epigenetic mechanisms which are yet to be clearly defined. NcRNAs have a strong influence on the "central dogma" of biology. The past view that all DNA was transcribed into RNA and then translated into protein has now been updated to include the fundamental role of ncRNAs on the regulation protein levels. Recently, several small and mid-sized ncRNAs have been described and are known to have a role in the regulation of transcription, post-transcription and translation. Small ncRNAs include PIWI-interacting RNAs (piRNAs), transcription initiation RNAs, and microRNAs (miRNAs) [8,51]. Mid-size ncRNAs include small nucleolar RNAs, promoter upstream transcripts, TSS-associated RNAs, and promoter-associated small RNAs. Long ncRNAs (lncRNAs) are most commonly associated with a reduction in transcription but may also have a role in the regulation of miRNA levels [8]. For a comprehensive review of miRNAs and blood pressure refer to the review paper by Marques et al. [51]. Here we will deliver a brief summary of some additional key miRNAs involved in HT as well as a review of lncRNAs.

MiRNAs are the most commonly studied small ncRNA; currently there is no research available investigating the involvement of the other types of small and mid-sized ncRNAs in EH. There are more than 1800 miRNAs in the genome, each approximately 22 nucleotides in length [52]. miRNAs down-regulate protein-coding genes by binding to target sequences in the $3^{\prime}$ ( $5^{\prime}$ targeting is uncommon but possible) untranslated region of a target mRNA, resulting in mRNA degradation or repression of mRNA translation [53] (Figure 4). Evidence suggests a single miRNA can regulate numerous mRNAs, so it is plausible that miRNAs are causative agents for complex deletions [53]. miRNAs are increasingly implicated as regulators of cardiovascular system [54], including modulation of arterial pressure [49] (Table 3).

Table 3. Summary of non-coding RNAs in relation to hypertension.

\begin{tabular}{|c|c|c|}
\hline Reference & Tissue Type/Sample Size & Findings \\
\hline Goyal, et al. [22] & $\begin{array}{l}\text { Rat: Tissues: brain; } 20 \text { maternal } \\
\text { low protein pups, } 17 \text { control pups }\end{array}$ & $\begin{array}{l}\text { mmu-miR-27a and mmu-miR-27b } \\
\text { regulate } A C E 1 \text { and was upregulated (3.3- } \\
\text { and } 8.8 \text {-fold respectively) in MLP rat; } \\
\text { mmu-mir-330 regulates angiotensin II } \\
\text { type } 2 \text { receptor }\left(\mathrm{AT}_{2}\right) \text { and was } \\
\text { downregulated } 3.5 \text {-fold in MLP rat. }\end{array}$ \\
\hline Sethupathy, et al. [55] & $\begin{array}{l}\text { Human: Fibroblasts from } \\
\text { monozygotic twin; } n=2\end{array}$ & $\begin{array}{l}\text { Has-miR-155 binds to } 3 \text { 'UTR of AGR1 } \\
\text { mRNA "A" allele causing a reduction in } \\
\text { AGTR1 mRNA, reducing the pressor } \\
\text { effect in response to angiotensin II. }\end{array}$ \\
\hline
\end{tabular}


Table 3. Cont.

\begin{tabular}{|c|c|c|}
\hline Reference & Tissue Type/Sample Size & Findings \\
\hline Cheng, et al. [56] & $\begin{array}{l}\text { Human: Endothelial cells from } \\
\text { pre-eclamptic placentas }\end{array}$ & $\begin{array}{l}\text { Has-miR-155 up-regulated in } \\
\text { preeclampsia placentas, indicating } \\
\text { involvement in regulation of } A G T R 1 .\end{array}$ \\
\hline Marques, et al. [57] & $\begin{array}{l}\text { Human: Tissue: kidney; Sample 1: } \\
42 \text { mixed sex, Polish individuals of } \\
\text { mixed HT status; Sample 2: } 22 \\
\text { male only, mixed HT status. All } \\
\text { samples untreated for HT }\end{array}$ & $\begin{array}{l}\text { Has-miR-181a \& has-miR- } 663 \text { is able to } \\
\text { bind 3'UTR of renin mRNA, found to be } \\
\text { underexpressed in EH. These miRNA able } \\
\text { to regulate renin mRNA directly, } \\
\text { explaining overexpression of renin in } \\
\text { EH kidney. }\end{array}$ \\
\hline Wang, et al. [58] & $\begin{array}{l}\text { Mouse: Tissue: Mesenteric } \\
\text { arterioles; } 16 \text { male C } 57 \mathrm{Bl} / 5 \text { mice; } \\
16 \text { sham mouse control }\end{array}$ & $\begin{array}{l}\text { siRNA targeting p22phox mRNA } \\
\text { demonstrated inhibition of contractile } \\
\text { response from angiotensin II, } \\
\text { consequently lowering BP. }\end{array}$ \\
\hline Cabili, et al. [59] & $\begin{array}{l}\text { Human: Tissue: } 24 \text { various and } \\
\text { cells lines; } 24 \text { human samples }\end{array}$ & $\begin{array}{l}\text { lincRNAs may promote the transcription } \\
\text { of their neighbouring coding genes, } \\
\text { including those implicated in EH and } \\
\text { BP regulation. }\end{array}$ \\
\hline Annilo, et al. [60] & $\begin{array}{l}\text { Human and Mouse: Various } \\
\text { tissues and cell lines; } \\
\mathrm{n}=\text { not disclosed }\end{array}$ & $\begin{array}{l}\text { Seven blood pressure candidate genes } \\
A D D 3, N P P A, A T P 1 A 1, N P R 2, C Y P 17 A 1, \\
A C S M 3 \text { and } S L C 14 A 2 \text { were connected } \\
\text { with cis-lncRNA transcripts. }\end{array}$ \\
\hline
\end{tabular}

In regards to the RAAS-regulated genes, it appears that miRNAs may also have a role modulating ACE mRNA transcription [29]. MiRNA has-miR-155 was found by Sethupathy et al. [55] to target the polymorphic sequence located in the 3'UTR of AGTR1 mRNA. This site has a Mendelian C (minor) and an A (major) allele. The minor-C allele is associated with EH [55]. Has-miR-155 binds most effectively to the A allele, leading to a reduction in AGTR1 mRNA in EH individuals who inherit this allele. Individuals with the $C$ allele did not have reduced AGTR1 mRNA and exhibited a greater pressor effect in response to angiotensin II [55]. Has-miR-155 is also found to be up-regulated in preeclampsia placentas; it regulates AGTR1 expression in umbilical vein endothelial cells [56]. A recent genome-wide association study documented expression of mRNAs and miRNAs in kidneys from untreated EH individuals, which were removed as a consequence of renal cancer [57]. Two miRNAs (has-miR-181a and has-miR-663) with the ability to bind to the 3'UTR of renin mRNA were found to be under-expressed in $\mathrm{EH}$. These miRNAs were able to regulate the expression of a reporter gene and renin-mRNA itself, which explains over-expression of renin mRNA seen in EH kidney [57]. In reference to DOT1 causing hypermethylation of H3 [37] (mentioned earlier), small interfering RNAs (siRNA) have been shown to have an opposite effect by silencing the expression of the DOT1 gene [61]. Furthermore, siRNAs have been observed to have a role in modulating the RAAS system [61]. Angiotensin II was shown to induce a contractile response in smooth muscle cells extracted from mice overexpressing p22phox, a subunit of NADPH oxidase responsible for activating NADPH oxidase and generating superoxide anions in atherosclerotic plaques in human blood vessels [62]. siRNA targeting p22phox inhibits the contractile response from angiotensin II, lowering blood pressure [58].

Long non-coding RNAs (IncRNAs), a heterogeneous group of non-coding transcripts longer than 200 nucleotides, regulate their targets by influencing epigenetic control, mRNA processing, translation or chromatin structure. LncRNAs have been implicated in several biological processes, including transcriptional regulation by epigenetic mechanisms [63]. An exemplary representation is $\mathrm{X}$-chromosome inactivation present in the female genome of mammals which involves the inactivation of one copy of a female sexual chromosome by DNA methylation. This process is coordinated by the X-inactive specific transcript (XIST) and the XIST antisense transcript (TSIX) ncRNAs, very long ncRNAs whose expression can be regulated by epigenetic mechanisms such as DNA methylation [50]. 
Large intergenic non-coding RNAs (lincRNAs) have been identified both as modulators of health development [64-66] and disease states [67], and may regulate the expression of neighbouring genes and distant loci [63]. LincRNAs are more tissue specific than are protein-coding genes [59], suggesting they have selective functions in different tissues. Cabili et al. [59] have described the annotation and tissue-specific expression of all lincRNAs. Their gene ontology analyses were based on lincRNA expression in different tissues [59]. The protein-coding genes located close to lincRNA loci included genes previously associated with $\mathrm{EH}$ and blood pressure regulation, for example, those encoding corticotropin-releasing hormone [59], suggesting many lincRNAs have an enhancer-like function that promotes transcription of their neighbouring coding genes [68]. LncRNAs have a potential to influence CVD, stroke, blood pressure and HT. Seven blood pressure candidate genes ADD3, NPPA, ATP1A1, NPR2, CYP17A1, ACSM3, and SLC14A2 were connected with cis-lncRNA transcripts [60]. Of these, the lncRNA NPPA-AS was selected for further investigation which revealed NPPA-AS has a demonstrated influence on the splicing of the natriuretic peptide precursor A (NPPA) gene (present in cardiac hypertrophy and heart failure) and, therefore, has potential CVD involvement [60].

\section{Conclusions}

We are entering a new era of understanding how the genome interacts with the environment to affect disease pathogenesis. There is now emerging evidence that epigenetic, as well as genetic, factors are key players in regulating and maintaining blood pressure, and strong evidence for a complex interaction of genetic and environmental factors that influence the risk of HT in each individual (Figure 5). Many epigenetic studies are, however, limited by the fact that only blood is studied rather than the effector tissues. The utility of blood methylation status in epigenetic research is yet to be determined. Furthermore, the polygenic complexity of HT and the limited knowledge on some of the non-coding RNAs makes it more challenging to decipher the exact mechanisms involved. Further studies in humans and in animal models will be needed to elucidate the exact mechanisms involved and to determine possible therapeutic applications.

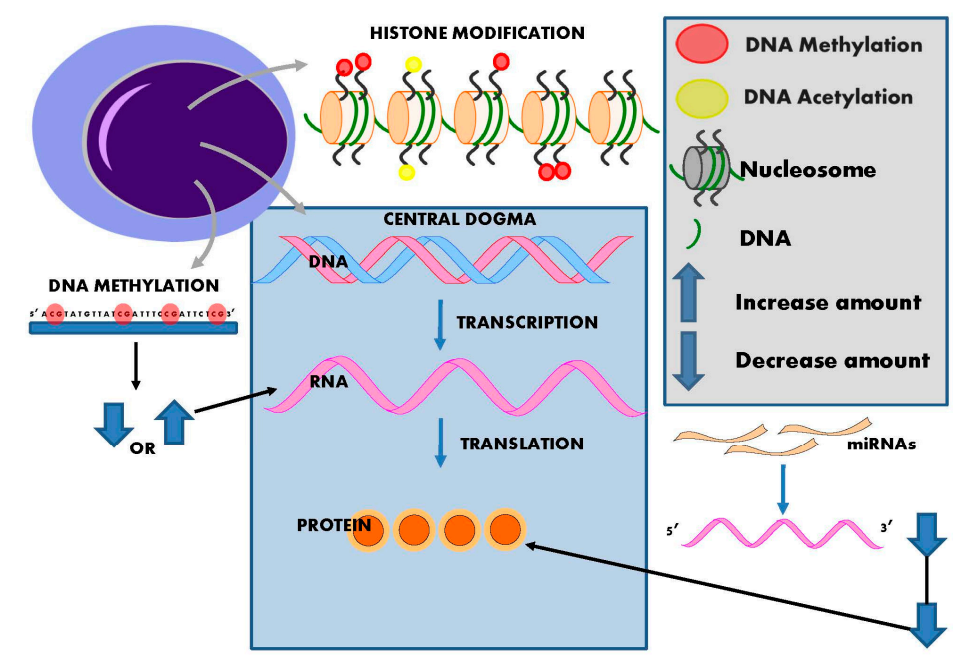

Figure 5. Impact of epigenetic modifications. DNA wrapped around nucleosomes are made up of four pairs of histone proteins. Histone proteins are prone to epigenetic modification, primarily acetylation and methylation but also phosphorylation, sumolyation, and biotinylation. These modifications change the formation of chromatin to either an open (active) or closed (inactive) state, thereby altering their transcriptional activity. DNA methylation changes the structure of DNA itself, allowing active transcription or silencing of genes. The outcome of DNA methylation is dependent on the location of the methylated site. miRNAs primarily target the 3' UTR of mRNA (although 5' targeting is possible). This negatively regulates the quantity of the encoded protein produced via degradation of mRNA molecules or by post-transcriptional regulation of mRNA stability. 
Acknowledgments: This work is supported by a National Health and Medical Research Council of Australia project grant and an Australian Postgraduate Award Scholarship.

Author Contributions: Both Ingrid A. Wise and Fadi J. Charchar contributed to the writing of this review.

Conflicts of Interest: The authors declare no conflict of interest.

\section{References}

1. Lim, S.S.; Vos, T.; Flaxman, A.D.; Danaei, G.; Shibuya, K.; Adair-Rohani, H.; AlMazroa, M.A.; Amann, M.; Anderson, H.R.; Andrews, K.G.; et al. A comparative risk assessment of burden of disease and injury attributable to 67 risk factors and risk factor clusters in 21 regions, 1990-2010: A systematic analysis for the global burden of disease study 2010. Lancet 2013, 380, 2224-2260. [CrossRef]

2. Poulter, N.R.; Prabhakaran, D.; Caulfield, M. Hypertension. Lancet 2015, 386, 801-812. [CrossRef]

3. Kunes, J.; Zicha, J. The interaction of genetic and environmental factors in the etiology of hypertension. Physiol. Res. 2009, 58 (Suppl. 2), S33-S41. [PubMed]

4. Loscalzo, J.; Handy, D.E. Epigenetic modifications: Basic mechanisms and role in cardiovascular disease (2013 grover conference series). Pulm. Circ. 2014, 4, 169-174. [CrossRef] [PubMed]

5. Lorenzen, J.M.; Martino, F.; Thum, T. Epigenetic modifications in cardiovascular disease. Basic Res. Cardiol. 2012, 107, 1-10. [CrossRef] [PubMed]

6. Khalil, C.A. The emerging role of epigenetics in cardiovascular disease. Ther. Adv. Chronic Dis. 2014, 5, 178-187. [CrossRef] [PubMed]

7. Wang, J.; Gong, L.; Tan, Y.; Hui, R.; Wang, Y. Hypertensive epigenetics: From DNA methylation to microRNAs. J. Hum. Hypertens. 2015, 29, 575-582. [CrossRef] [PubMed]

8. Bátkai, S.; Thum, T. MicroRNAs in hypertension: Mechanisms and therapeutic targets. Curr. Hypertens. Rep. 2012, 14, 79-87. [CrossRef] [PubMed]

9. Millis, R.M. Epigenetics and hypertension. Curr. Hypertens. Rep. 2011, 13, 21-28. [CrossRef] [PubMed]

10. Raftopoulos, L.; Katsi, V.; Makris, T.; Tousoulis, D.; Stefanadis, C.; Kallikazaros, I. Epigenetics, the missing link in hypertension. Life Sci. 2015, 129, 22-26. [CrossRef] [PubMed]

11. López-Jaramillo, P.; Camacho, P.A.; Forero-Naranjo, L. The role of environment and epigenetics in hypertension. Expert Rev. Cardiovasc. Ther. 2013, 11, 1455-1457. [CrossRef] [PubMed]

12. Rakyan, V.K.; Hildmann, T.; Novik, K.L.; Lewin, J.; Tost, J.; Cox, A.V.; Andrews, T.D.; Howe, K.L.; Otto, T.; Olek, A.; et al. DNA methylation profiling of the human major histocompatibility complex: A pilot study for the human epigenome project. PLoS Biol. 2004, 2. [CrossRef] [PubMed]

13. Abbott, A. Project set to map marks on genome. Nature 2010, 463, 596-597. [CrossRef] [PubMed]

14. Kelsey, G.; Feil, R. New insights into establishment and maintenance of DNA methylation imprints in mammals. Philos. Trans. R. Soc. Biol. Sci. 2013, 368. [CrossRef]

15. Kunes, J.; Kadlecova, M.; Vaneckova, I.; Zicha, J. Critical developmental periods in the pathogenesis of hypertension. Physiol. Res. 2012, 61 (Suppl. 1), S9-S17. [PubMed]

16. Wilson, A.G. Epigenetic regulation of gene expression in the inflammatory response and relevance to common diseases. J. Periodontol. 2008, 79, 1514-1519. [PubMed]

17. Miranda, T.B.; Jones, P.A. DNA methylation: The nuts and bolts of repression. J. Cell. Physiol. 2007, 213, 384-390. [CrossRef] [PubMed]

18. Fouse, S.D.; Nagarajan, R.P.; Costello, J.F. Genome-scale DNA methylation analysis. Epigenomics 2010, 2, 105-117. [CrossRef] [PubMed]

19. Smolarek, I.; Wyszko, E.; Barciszewska, A.M.; Nowak, S.; Gawronska, I.; Jablecka, A.; Barciszewska, M.Z. Global DNA methylation changes in blood of patients with essential hypertension. Med. Sci. Monit. Basic Res. 2010, 16, CR149-CR155.

20. Kato, N.; Loh, M.; Takeuchi, F.; Verweij, N.; Wang, X.; Zhang, W.; Kelly, T.N.; Saleheen, D.; Lehne, B.; Leach, I.M.; et al. Trans-ancestry genome-wide association study identifies 12 genetic loci influencing blood pressure and implicates a role for DNA methylation. Nat. Genet. 2015, 47, 1282-1293. [CrossRef] [PubMed]

21. Friso, S.; Pizzolo, F.; Choi, S.-W.; Guarini, P.; Castagna, A.; Ravagnani, V.; Carletto, A.; Pattini, P.; Corrocher, R.; Olivieri, O. Epigenetic control of $11 \beta$-hydroxysteroid dehydrogenase 2 gene promoter is related to human hypertension. Atherosclerosis 2008, 199, 323-327. [CrossRef] [PubMed] 
22. Goyal, R.; Goyal, D.; Leitzke, A.; Gheorghe, C.P.; Longo, L.D. Brain renin-angiotensin system: Fetal epigenetic programming by maternal protein restriction during pregnancy. Reprod. Sci. 2010, 17, 227-238. [CrossRef] [PubMed]

23. Wang, X.; Falkner, B.; Zhu, H.; Shi, H.; Su, S.; Xu, X.; Sharma, A.K.; Dong, Y.; Treiber, F.; Gutin, B.; et al. A genome-wide methylation study on essential hypertension in young african american males. PLoS ONE 2013, 8, e53938. [CrossRef] [PubMed]

24. Pei, F.; Wang, X.; Yue, R.; Chen, C.; Huang, J.; Huang, J.; Li, X.; Zeng, C. Differential expression and DNA methylation of angiotensin type $1 \mathrm{~A}$ receptors in vascular tissues during genetic hypertension development. Mol. Cell. Biochem. 2015, 402, 1-8. [CrossRef] [PubMed]

25. Rivière, G.; Lienhard, D.; Andrieu, T.; Vieau, D.; Frey, B.M.; Frey, F.J. Epigenetic regulation of somatic angiotensin-converting enzyme by DNA methylation and histone acetylation. Epigenetics 2011, 6, 478-489. [CrossRef] [PubMed]

26. Lee, H.-A.; Baek, I.; Seok, Y.M.; Yang, E.; Cho, H.-M.; Lee, D.-Y.; Hong, S.H.; Kim, I.K. Promoter hypomethylation upregulates $\mathrm{Na}^{+}-\mathrm{K}^{+}-2 \mathrm{Cl}^{-}$cotransporter 1 in spontaneously hypertensive rats. Biochem. Biophys. Res. Commun. 2010, 396, 252-257. [CrossRef] [PubMed]

27. Ferrari, P.; Sansonnens, A.; Dick, B.; Frey, F.J. In vivo 11ß-HSD-2 activity variability, salt-sensitivity, and effect of licorice. Hypertension 2001, 38, 1330-1336. [CrossRef] [PubMed]

28. Udali, S.; Guarini, P.; Moruzzi, S.; Choi, S.-W.; Friso, S. Cardiovascular epigenetics: From DNA methylation to microRNAs. Mol. Asp. Med. 2013, 34, 883-901. [CrossRef] [PubMed]

29. Bogdarina, I.; Welham, S.; King, P.J.; Burns, S.P.; Clark, A.J. Epigenetic modification of the renin-angiotensin system in the fetal programming of hypertension. Circ. Res. 2007, 100, 520-526. [CrossRef] [PubMed]

30. Zhang, Y.; Hong, X.-M.; Xing, H.-X.; Li, J.-P.; Huo, Y.; Xu, X.-P. E112D polymorphism in the prolylcarboxypeptidase gene is associated with blood pressure response to benazepril in chinese hypertensive patients. Chin. Med. J. 2009, 122, 2461-2465. [PubMed]

31. Esler, M.; Eikelis, N.; Schlaich, M.; Lambert, G.; Alvarenga, M.; Kaye, D.; El-Osta, A.; Guo, L.; Barton, D.; Pier, C.; et al. Human sympathetic nerve biology: Parallel influences of stress and epigenetics in essential hypertension and panic disorder. Ann. N. Y. Acad. Sci. 2008, 1148, 338-348. [CrossRef] [PubMed]

32. Jenuwein, T.; Allis, C.D. Translating the histone code. Science 2001, 293, 1074-1080. [CrossRef] [PubMed]

33. Han, S.; Uludag, M.O.; Usanmaz, S.E.; Ayaloglu-Butun, F.; Akcali, K.C.; Demirel-Yilmaz, E. Resveratrol affects histone 3 lysine 27 methylation of vessels and blood biomarkers in DOCA salt-induced hypertension. Mol. Biol. Rep. 2015, 42, 35-42. [CrossRef] [PubMed]

34. Fish, J.E.; Matouk, C.C.; Rachlis, A.; Lin, S.; Tai, S.C.; D'Abreo, C.; Marsden, P.A. The expression of endothelial nitric-oxide synthase is controlled by a cell-specific histone code. J. Biol. Chem. 2005, 280, 24824-24838. [CrossRef] [PubMed]

35. Lee, H.-A.; Cho, H.-M.; Lee, D.-Y.; Kim, K.-C.; Han, H.S.; Kim, I.K. Tissue-specific upregulation of angiotensin-converting enzyme 1 in spontaneously hypertensive rats through histone code modifications. Hypertension 2012, 59, 621-626. [CrossRef] [PubMed]

36. Cho, H.-M.; Lee, D.-Y.; Kim, H.Y.; Lee, H.-A.; Seok, Y.M.; Kim, I.K. Upregulation of the $\mathrm{Na}^{+}-\mathrm{K}^{+}-2 \mathrm{Cl}^{-}$ cotransporter 1 via histone modification in the aortas of angiotensin II-induced hypertensive rats. Hypertens. Res. 2012, 35, 819-824. [CrossRef] [PubMed]

37. Duarte, J.D.; Zineh, I.; Burkley, B.; Gong, Y.; Langaee, T.Y.; Turner, S.T.; Chapman, A.B.; Boerwinkle, E.; Gums, J.G.; Cooper-DeHoff, R.M.; et al. Effects of genetic variation in H3K79 methylation regulatory genes on clinical blood pressure and blood pressure response to hydrochlorothiazide. J. Transl. Med. 2012, 10, 56. [CrossRef] [PubMed]

38. Mu, S.; Shimosawa, T.; Ogura, S.; Wang, H.; Uetake, Y.; Kawakami-Mori, F.; Marumo, T.; Yatomi, Y.; Geller, D.S.; Tanaka, H.; et al. Epigenetic modulation of the renal $\beta$-adrenergic-WNK4 pathway in salt-sensitive hypertension. Nat. Med. 2011, 17, 573-580. [CrossRef] [PubMed]

39. Bhatt, S.R.; Lokhandwala, M.F.; Banday, A.A. Resveratrol prevents endothelial nitric oxide synthase uncoupling and attenuates development of hypertension in spontaneously hypertensive rats. Eur. J. Pharmacol. 2011, 667, 258-264. [CrossRef] [PubMed]

40. Rodriguez-Iturbe, B. Arteriolar remodeling in essential hypertension: Are connective tissue growth factor and transforming growth factor involved? Kidney Int. 2006, 69, 1104-1105. [CrossRef] [PubMed] 
41. Katholi, R.E.; Naftilan, A.J.; Oparil, S. Importance of renal sympathetic tone in the development of DOCA-salt hypertension in the rat. Hypertension 1980, 2, 266-273. [CrossRef] [PubMed]

42. DiBona, G.F. Physiology in perspective: The wisdom of the body. Neural control of the kidney. Am. J. Physiol. Regul. Integr. Comp. Physiol. 2005, 289, R633-R641. [CrossRef] [PubMed]

43. Guild, S.-J.; Eppel, G.A.; Malpas, S.C.; Rajapakse, N.W.; Stewart, A.; Evans, R.G. Regional responsiveness of renal perfusion to activation of the renal nerves. Am. J. Physiol. Regul. Integr. Comp. Physiol. 2002, 283, R1177-R1186. [CrossRef] [PubMed]

44. Kahle, K.T.; Ring, A.M.; Lifton, R.P. Molecular physiology of the WNK kinases. Annu. Rev. Physiol. 2008, 70, 329-355. [CrossRef] [PubMed]

45. Chiga, M.; Rai, T.; Yang, S.-S.; Ohta, A.; Takizawa, T.; Sasaki, S.; Uchida, S. Dietary salt regulates the phosphorylation of OSR1/SPAK kinases and the sodium chloride cotransporter through aldosterone. Kidney Int. 2008, 74, 1403-1409. [CrossRef] [PubMed]

46. O’Reilly, M.; Marshall, E.; MacGillivray, T.; Mittal, M.; Xue, W.; Kenyon, C.J.; Brown, R.W. Dietary electrolyte-driven responses in the renal WNK kinase pathway in vivo. J. Am. Soc. Nephrol. 2006, 17, 2402-2413. [CrossRef] [PubMed]

47. Lee, H.; Rezai-Zadeh, N.; Seto, E. Negative regulation of histone deacetylase 8 activity by cyclic AMP-dependent protein kinase A. Mol. Cell. Biol. 2004, 24, 765-773. [CrossRef] [PubMed]

48. Mulholland, N.M.; Snyder, S.K.; Kolla, S.S.; Smith, C.L. Chromatin-dependent regulation of the MMTV promoter by cAMP signaling is mediated through distinct pathways. Exp. Cell Res. 2003, 287, 361-373. [CrossRef]

49. Nguyen Dinh Cat, A.L.; Ouvrard-Pascaud, A.; Tronche, F.; Clemessy, M.; Gonzalez-Nunez, D.; Farman, N.; Jaisser, F. Conditional transgenic mice for studying the role of the glucocorticoid receptor in the renal collecting duct. Endocrinology 2009, 150, 2202-2210. [CrossRef] [PubMed]

50. Costa, F.F. Non-coding RNAs, epigenetics and complexity. Gene 2008, 410, 9-17. [CrossRef] [PubMed]

51. Marques, F.Z.; Charchar, F.J. MicroRNAs in essential hypertension and blood pressure regulation. In MicroRNA: Medical Evidence; Springer: Berlin, Germany, 2015; pp. 215-235.

52. Marques, F.Z.; Morris, B.J. Neurogenic hypertension: Revelations from genome-wide gene expression profiling. Curr. Hypertens. Rep. 2012, 14, 485-491. [CrossRef] [PubMed]

53. Huntzinger, E.; Izaurralde, E. Gene silencing by microRNAs: Contributions of translational repression and mRNA decay. Nat. Rev. Genet. 2011, 12, 99-110. [CrossRef] [PubMed]

54. Small, E.M.; Olson, E.N. Pervasive roles of microRNAs in cardiovascular biology. Nature 2011, 469, $336-342$. [CrossRef] [PubMed]

55. Sethupathy, P.; Borel, C.; Gagnebin, M.; Grant, G.R.; Deutsch, S.; Elton, T.S.; Hatzigeorgiou, A.G.; Antonarakis, S.E. Human microRNA-155 on chromosome 21 differentially interacts with its polymorphic target in the agtr1 $3^{\prime}$ untranslated region: A mechanism for functional single-nucleotide polymorphisms related to phenotypes. Am. J. Hum. Genet. 2007, 81, 405-413. [CrossRef] [PubMed]

56. Cheng, W.; Liu, T.; Jiang, F.; Liu, C.; Zhao, X.; Gao, Y.; Wang, H.; Liu, Z. MicroRNA-155 regulates angiotensin II type 1 receptor expression in umbilical vein endothelial cells from severely pre-eclamptic pregnant women. Int. J. Mol. Med. 2011, 27, 393-399. [PubMed]

57. Marques, F.Z.; Campain, A.E.; Tomaszewski, M.; Zukowska-Szczechowska, E.; Yang, Y.H.J.; Charchar, F.J.; Morris, B.J. Gene expression profiling reveals renin mRNA overexpression in human hypertensive kidneys and a role for microRNAs. Hypertension 2011, 58, 1093-1098. [CrossRef] [PubMed]

58. Wang, D.; Chabrashvili, T.; Borrego, L.; Aslam, S.; Umans, J.G. Angiotensin II infusion alters vascular function in mouse resistance vessels: Roles of $\mathrm{O}^{-\cdot 2}$ and endothelium. J. Vasc. Res. 2005, 43, 109-119. [CrossRef] [PubMed]

59. Cabili, M.N.; Trapnell, C.; Goff, L.; Koziol, M.; Tazon-Vega, B.; Regev, A.; Rinn, J.L. Integrative annotation of human large intergenic noncoding RNAs reveals global properties and specific subclasses. Genes Dev. 2011, 25, 1915-1927. [CrossRef]

60. Annilo, T.; Kepp, K.; Laan, M. Natural antisense transcript of natriuretic peptide precursor A (NPPA): Structural organization and modulation of NPPA expression. BMC Mol. Biol. 2009, 10. [CrossRef] [PubMed]

61. Yu, Z.; Kong, Q.; Kone, B.C. CREB trans-activation of disruptor of telomeric silencing-1 mediates forskolin inhibition of ctgf transcription in mesangial cells. Am. J. Physiol. Ren. Physiol. 2010, 298, F617-F624. [CrossRef] [PubMed] 
62. Guzik, T.J.; Sadowski, J.; Guzik, B.; Jopek, A.; Kapelak, B.; Przybyłowski, P.; Wierzbicki, K.; Korbut, R.; Harrison, D.G.; Channon, K.M. Coronary artery superoxide production and nox isoform expression in human coronary artery disease. Arterioscler. Thromb. Vasc. Biol. 2006, 26, 333-339. [CrossRef] [PubMed]

63. Esteller, M. Non-coding RNAs in human disease. Nat. Rev. Genet. 2011, 12, 861-874. [CrossRef] [PubMed]

64. Ng, S.Y.; Johnson, R.; Stanton, L.W. Human long non-coding RNAs promote pluripotency and neuronal differentiation by association with chromatin modifiers and transcription factors. EMBO J. 2012, 31, 522-533. [CrossRef] [PubMed]

65. Paralkar, V.R.; Weiss, M.J. A new “Linc” between noncoding RNAs and blood development. Genes Dev. 2011, 25, 2555-2558. [CrossRef] [PubMed]

66. Pauli, A.; Rinn, J.L.; Schier, A.F. Non-coding RNAs as regulators of embryogenesis. Nat. Rev. Genet. 2011, 12, 136-149. [CrossRef] [PubMed]

67. Niland, C.N.; Merry, C.R.; Khalil, A.M. Emerging roles for long non-coding RNAs in cancer and neurological disorders. Front. Genet. 2012, 3. [CrossRef] [PubMed]

68. Ørom, U.A.; Derrien, T.; Beringer, M.; Gumireddy, K.; Gardini, A.; Bussotti, G.; Lai, F.; Zytnicki, M.; Notredame, C.; Huang, Q.; et al. Long noncoding RNAs with enhancer-like function in human cells. Cell 2010, 143, 46-58. [CrossRef] [PubMed]

(C) 2016 by the authors; licensee MDPI, Basel, Switzerland. This article is an open access article distributed under the terms and conditions of the Creative Commons by Attribution (CC-BY) license (http://creativecommons.org/licenses/by/4.0/). 